\title{
A Rhizogenic Biostimulant Effect on Soil Fertility and Roots Growth of Turfgrass
}

\author{
Salima Yousfi ${ }^{1}$, José Marín ${ }^{2,3}{ }^{(D}$, Lorena Parra ${ }^{1,4}{ }^{(}$, Jaime Lloret $^{4}\left(\mathbb{D}\right.$ and Pedro V. Mauri ${ }^{1, *(1)}$ \\ 1 Instituto Madrileño de Investigación y Desarrollo Rural, Agrario y Alimentario (IMIDRA), \\ Departamento de Investigación Agroambiental, 28805 Madrid, Spain; salima.yousfi@madrid.org (S.Y.); \\ loparbo@doctor.upv.es (L.P.) \\ 2 AreaVerde MG Projects Madrid, Departamento de Investigación e Innovación, 28050 Madrid, Spain; \\ jmarin@areaverde.es \\ 3 Departamento de Producción Agraria, Universidad Politécnica de Madrid, 28040 Madrid, Spain \\ 4 Instituto de Investigación para la Gestión Integrada de Zonas Costeras, Universitat Politècnica de València, \\ 46730 Grao de Gandia, Valencia, Spain; jlloret@dcom.upv.es \\ * Correspondence: pedro.mauri@madrid.org
}

Citation: Yousfi, S.; Marín, J.; Parra, L.; Lloret, J.; Mauri, P.V. A Rhizogenic Biostimulant Effect on Soil Fertility and Roots Growth of Turfgrass. Agronomy 2021, 11, 573. https:// doi.org/10.3390/agronomy11030573

Academic Editor: Francesc Xavier Prenafeta Boldú

Received: 12 February 2021

Accepted: 15 March 2021

Published: 18 March 2021

Publisher's Note: MDPI stays neutral with regard to jurisdictional claims in published maps and institutional affiliations.

Copyright: (c) 2021 by the authors. Licensee MDPI, Basel, Switzerland. This article is an open access article distributed under the terms and conditions of the Creative Commons Attribution (CC BY) license (https:/ / creativecommons.org/licenses/by/ $4.0 /)$.

\begin{abstract}
The excessive use of chemical fertilizers can lead to severe environmental damages. In recent decades, the application of biostimulants to improve soil composition and stimulate plant growth has contributed significantly to environmental preservation. In this paper, we studied the effect of a rhizogenic biostimulant, obtained from fulvic acids, probiotics, and prebiotics, on the fertility of two types of soils, sandy and sandy loam soils, in which turfgrass was growing. Soil samples from plots treated with biostimulant and controls (untreated plots) were collected. The analyzed parameters from the soil include organic matter, microbial activity, soil chemical composition, catalase, dehydrogenase, and phosphatase enzyme activities. Moreover, root lengths was examined and compared in turfgrass species. The biostimulant application improved microbial activity, organic matter, and enzymatic activity in both types of soils. The soil calcium, potassium, magnesium, and phosphorus content increased with the biostimulant application, whereas $\mathrm{pH}$ and electrical conductivity decreased. The most relevant improvement was a $77 \%$ increase of calcium for sandy loam soil and 38\% increase in potassium for sandy soil. Biostimulant application led to a significant increase in turf root length. This increase was greater for sandy soil than in sandy loam soil with an increment of $43 \%$ and $34 \%$ respectively, compared to control.
\end{abstract}

Keywords: soil health; biofertlizer; microbial activity; organic matter; enzyme activity; soil nutrients; radicular system; fulvic acids; probiotics; rhizogenesis

\section{Introduction}

Chemical fertilization of soil currently corrects soil nutrient deficiency and improves plant growth. However, the excessive use of chemical fertilizers causes soil toxicity [1] and surface and groundwater contamination. The excess of nitrates, urea, and phosphates can lead to accumulation, which can harm the environment and pose a risk to human health. Furthermore, this environmental pollution may increase in the future because of the predicted decrease in precipitation and the increase in evapotranspiration in many regions of the world in the context of global warming. The large amounts of nitrogen, potassium, and phosphorus contributed by commercial fertilizers can also disrupt plant nutrient balance and uptake. The soil microbial activity is also impaired by the excess use of fertilizers [2,3], and overuse of nitrogen fertilizers limits the activity of soil microorganisms. Indeed, excessive application of fertilizers contributes to decreasing soil organic matter and fertility [4], affects the diversity of the soil microbiome [5,6], affects the nitrogen cycle and bacterial populations [7], and reduces soil $\mathrm{pH}$, which can lead to a reduction in the diversity of bacterial communities [8]. 
In recent decades, the regulations of the European Union governing the use of fertilizers have become tighter, and the legislation of several countries around the world regulates the percentages and amounts of fertilizer that can be applied to crops. Studies of indicators that reflect soil fertility [1], as well as the prediction of the soil organic carbon and nutrient indicators [9], can contribute to the efficient management of crop fertilization. In this context, the application of biostimulants to improve soil composition and stimulate plant growth has gained relevance in agricultural management. The use of natural biostimulants improve soil characteristics and nutrient availability for crops can allow a reduction in the use of chemical fertilizers, which in intensive application cause a serious problem in soil health [10]. Biostimulants have been defined as materials that, in small amounts, promote plant growth [11,12]. They have also been described as any substance or microorganism applied to soils with the aim of improving plant nutritional efficiency and tolerance to abiotic stress [13]. Natural biostimulants facilitate environmental protection and are cost-effective alternatives to synthetic products such as fertilizers, crop protection products and plant growth regulators [14]. These products can improve soil chemical and biological properties, stimulate plant growth, and preserve soil fertility [15]. Biostimulants also increase root biomass, nutrient translocation, and soil enzyme activity [16]. There are many groups and forms of biostimulants, including enzymes, proteins, amino acids, micronutrients, and other compounds [17]. Natural stimulants, such as phenols, salicylic acid, humic and fulvic acids, and protein hydrolases, are often included under the term biostimulants [18,19]. Moreover, fungi and bacteria are also an important group of plant biostimulants that can alter the community of soil microorganisms [17]. In this context, some authors [20,21] state that prebiotics are natural products, including sewage sludge, compost, humus, animal manure, and chitin-bearing wastes, which improve soil biochemical activity and microbial population. Likewise, the applications of prebiotics in soils can improve crop growth by producing bioactive substances such as hormones and enzymes, controlling soil diseases, accelerating decomposition of soil lignin materials and delivering inorganic nutrients for plant uptake [22]. Moreover, researchers [23] stated that probiotics are accepted as advantageous microorganisms, which, once introduced into soil, should develop a significant biomass level with several plant beneficial traits. Biostimulant composed of fulvic acids also improved soil properties and plant growth. Similarly, the addition of fulvic acids to soils can have important implications for soil physical, chemical, and biological characteristics [24,25]. Humic and fulvic acids contain nutrient cations, such as potassium, calcium, and magnesium, in easily assimilable form for plants [26]. Concerning the biological effect of humic substances, researchers [27] reported that addition of these substances enhance soil fertility through their effects on the composition of microbial populations. Calcium lignosulfonate is another element added to biostimulants and which can also improve the soil. The calcium lignosulfonate could be used as soil nutrient source and as a solution additive to resolve the problems of soil degradation and caking [28]; it can also improve soil structure and is used to stabilize cohesive to non-cohesive soils [29]. In recent years, biostimulants have become a useful approach to soil health and environment protection. Several studies have testing effect of biostimulants on soil compositions and properties and on plant growth. The use of biostimulants for soil restoration has been evaluated [30]. The authors reported that under semiarid climatic conditions the application of biostimulants augmented soil enzymatic activities, induced changes in microbial community, and supported soil protection against erosion and contributed to its restoration. Moreover, other studies indicated that biostimulants can increase the activity of rhizosphere microbes and soil enzymes, and the production of soil growth regulators [31,32].

Biostimulants can stimulate the breakdown and mineralization of soil organic matter permitting the improvement of soil nitrogen availability [33]. The European Biostimulants Industry Council also has several studies on biostimulants and defined biostimulants containing organisms whose function, after application to plants or the rhizosphere, is to stimulate the natural procedures to improve nutrient uptake and nutrient efficiency [34]. Biostimulants help plants tolerate biotic and abiotic stresses, increase their nutrient use 
efficiency and show beneficial effects on soil properties such as $\mathrm{pH}$, soil electrical conductivity (EC) and soil nitrogen [35]. Moreover, soil agronomical treatments affect strongly the enzymatic activity compared to other soil biochemical parameters [36]. Soil enzymes activities are defined as potential indicators of soil quality $[37,38]$ due to their relationship to soil biology and the cycles of nutrients in the soil [31]. Catalase and dehydrogenase are among the best known enzymes related to soil biological characteristics and fertility. Dehydrogenases activity is considered as good indicator of oxidative metabolism in soils and microbiological activity [39]. Moreover, catalase enzyme is defined an important indicator of soil fertility and aerobic microorganisms [39]. Additionally, phosphatase soil enzyme activity catalyzes the hydrolysis of organic phosphorus compounds and transforms them into an inorganic form of phosphorus, which is assimilated by plants and microorganisms [40].

On other hand, several investigations reported the importance of the use of biostimulants in root growth. Biostimulants improved several vegetative growth characteristics of shoots and roots including length and dry weight [41]. Other studies on the effect of biostimulants on root growth also indicated that the addition of biostimulants to plants modifies the morphology of plant root and biostimulants induce better uptake of nutrients via an increase in the absorptive surface area [42,43]. Biostimulant products can be introduced to crop leaves, seeds or soil as a means of stimulating root growth [44]. A review [16] of biostimulants highlighted their advantages, suggesting their usefulness in reducing fertilizer use without negatively affecting yield and summarized the various mechanisms proposed to explain soil and plant improvement observed with the use of biostimulants.

In this paper, we studied the effects of a commercial rhizogenic biostimulant on soil composition and plant root growth. We evaluated soil chemical composition, organic matter, microbial activity and catalase, dehydrogenase, and phosphatase enzyme activities, in two types of soils (sandy loam and sandy soils). Moreover, root length of turf graminea were also examined. In addition, the design of this study is unique in that it evaluates biostimulant effects on two types of soils and on soil properties and plant root growth. Understanding the effects of this biostimulant on soil fertility can contribute to the design of more efficient fertilization strategies, which enhance soil composition and, at the same time, preserve soils and help in the environmental sustainability.

\section{Materials and Methods}

\subsection{Soil Texture, Plant Material, and Growth Conditions}

Field experiments were conducted in 2019 at two sites, the Madrid Institute for Rural Research and Agrarian Development and Food (IMIDRA) characterized by sandy loam soil and at the Encín Golf Club, characterized by sandy soil. The texture of the two types of soil is described in Table 1. In both soils, turf graminea were cultivated. Grass mixture formed by Lolium perenne L.-Festuca arundinacea Schreb.-Poa pratensis L. was cultivated in sandy loam soil, while in the sandy soil, turfgrass Agrostis stolonifera Tee One was used. Both experiments were well irrigated daily. Full irrigation to $100 \%$ of container capacity was applied and controlled by the Rain Bird system irrigation (ESP-LXME Model, Tucson, AZ, USA).

Table 1. Texture and nitrogen content of the two types of soils studied.

\begin{tabular}{ccc}
\hline & Soil 1 & Soil 2 \\
\hline Clay & $11 \%$ & $1 \%$ \\
Silt & $21.5 \%$ & $6.5 \%$ \\
Sandy & $67 \%$ & $92 \%$ \\
Nitrogen & $0.01 \%$ & $0.04 \%$ \\
Texture & Sandy loam & Sandy \\
\hline
\end{tabular}




\subsection{Biostimulant Characteristics and Application}

The product applied is a rhizogenic biostimulant composed of fulvic acids, calcium nutrient (10\% of complex Calcium), calcium lignosulfonate, and a minimum trace of nitrogen. Moreover, the biostimulant also contains prebiotic molecules that are generated from the fermentation of humic acids, probiotic molecules formed by a bacterial strain of Bacillus sublitis (with high capacity for soil and plant growth promotion) with a concentration in the product of at least $6 \times 10^{5} \mathrm{CFU} / \mathrm{mL}$. The biostimulant is prepared and commercialized by the Agrotechnology Group (Alicante, Spain). The biostimulant was applied to the soil cultivated with turfgrass from March to November 2019, every 20 days and with $10 \mathrm{~L} / \mathrm{ha}$ of the product solution (for the type of soils) mixed in $80 \mathrm{~L}$ of water. For the sandy loam soil, three plots of $4.5 \mathrm{~m}^{2}$ were treated with biostimulant, and another three plots of $4.5 \mathrm{~m}^{2}$ were used as controls (untreated). Meanwhile, for the sandy soil, the study was achieved in an area of $600 \mathrm{~m}^{2}$ divided into three replicates (three zones) with biostimulant application and another three replicates as controls (untreated). Soil samples were collected at the end of the experiments, in 0-20 cm of soil depth and in each replicate. Soil auger of $10.7 \mathrm{~cm}$ of diameter and $17 \mathrm{~cm}$ depth was used for soil sampling. In each replicate, several core samples were taken and pooled prior to analysis.

\subsection{Soil Chemical Composition, Microbial Activity, and Organic Matter}

Soil calcium $\left(\mathrm{Ca}^{2+}\right)$, magnesium $\left(\mathrm{Mg}^{2+}\right)$ and potassium $\left(\mathrm{K}^{+}\right)$content was determined by atomic absorption spectrometry methods The determination of soil assimilable phosphorus $(\mathrm{P})$ was done using the Olsen method [45]. The exchangeable cations of the soil were displaced by successive extractions of a $1 \mathrm{~N}$ solution of ammonium acetate at $\mathrm{pH}=7$ and it is determined in this extract. Soil pH and the soil electrical conductivity (EC) were also determined. Microbial activity was analyzed in soil samples by respiration method following the method of Gracía and Hernandez [46]. Moreover, soil organic matter was determined by the Walkey and Black method [47].

\subsection{Soil Enzyme Activity Measurement}

The Dehydrogenase enzyme activity was determined by spectrophotometry following Trevors et al. methods [48] and modified by Garcia et al. [49]. The catalase activity was determined by permanganometry following the Jonhson and Temple method [50]. Finally, the phosphatase activity was measured by permanganometry using the Tabatabai and Bremner method [51].

\subsection{Root Growth}

Three replicates of roots were sampled for each treatment (at the end of the experiment) using an auger of $10 \mathrm{~cm}$ diameter and $22 \mathrm{~cm}$ depth. Root samples were washed, and the length of each replicate was measured using a ruler with $1 \mathrm{~mm}$ of precision.

\subsection{Statistical Analysis}

Data were subjected to factorial analyses of variance (ANOVA) to test the effects of biostimulant on soil characteristics and root growth. Data of all parameters studied were analyzed separately for each type of soils. Means were compared by Tukey's honestly significant difference (HSD) for each type of soil and turfgrass. A bivariate Pearson correlation procedure was used to analyze the relationships of root length with soil chemical parameters, organic matter, microbial activity, and enzymatic activity under biostimulant treatment for each type of soil. Statistical analysis was done using IBM SPSS Statistics 24 (SPSS Inc., Chicago, IL, USA). Sigma-Plot 11.0 for Windows (Systat Software Inc., Point Richmond, CA, USA) was used for the creation of figures. Moreover, canonical analysis combining all data measured under biostimulant application and control for each type of soil was performed using the Past (PAleontological STatistics) program. 


\section{Results}

\subsection{Effect of the Biostimulant on Soil Chemical Composition}

The biostimulants caused a significant decrease in pH and EC in both soils (Table 2). In addition, biostimulant application had a marked effect on the concentration of $\mathrm{Ca}^{2+}$, $\mathrm{Mg}^{2+}, \mathrm{P}$, and $\mathrm{K}^{+}$(Table 2), with higher ion concentrations observed under biostimulant application for $\mathrm{Ca}^{2+}$ in sandy loam soil compared to control. Biostimulant increased $\mathrm{Ca}^{2+}$, $\mathrm{Mg}^{2+}, \mathrm{K}^{+}$, and $\mathrm{P}$ by $77 \%, 14 \%, 5 \%$, and $34 \%$, respectively, in sandy loam soil and by $35 \%$, $15 \%, 38 \%$, and $21 \%$ in sandy soil compared to control.

Table 2. Biostimulant effect on soil $\mathrm{pH}, \mathrm{EC}$ and $\mathrm{Ca}^{2+}, \mathrm{Mg}^{2+}, \mathrm{K}^{+}$, and phosphorus ion concentrations in the sandy loam and sandy soils. Means followed by different letters within a column and within a soil type are significantly different $(p<0.05)$ according to Tukey's HSD test. Significance levels (Sig): ${ }^{* * *} p<0.001 ;{ }^{* *} p<0.010$.

\begin{tabular}{|c|c|c|c|c|c|c|c|}
\hline Soil & Treatment & $\mathrm{pH}$ & $\mathrm{EC} \mathrm{dS} / \mathrm{m}$ & $\mathrm{Ca}^{2+}(\mathrm{mg} / \mathrm{kg})$ & $\mathrm{Mg}^{2+}(\mathrm{mg} / \mathrm{kg})$ & $P(\mathrm{mg} / \mathrm{kg})$ & $\mathrm{K}^{+}(\mathrm{mg} / \mathrm{kg})$ \\
\hline \multirow{5}{*}{ Sandy loam } & \multirow{2}{*}{ Control } & $8.89^{c}$ & $0.38^{\mathrm{b}}$ & $647.75^{\mathrm{a}}$ & $186.75^{\mathrm{a}}$ & $23.60^{a}$ & $163.50^{\mathrm{a}}$ \\
\hline & & \pm 0.10 & \pm 0.05 & \pm 52.41 & \pm 10.54 & \pm 0.84 & \pm 10.08 \\
\hline & \multirow{2}{*}{ Biostimulant } & $8.31^{\mathrm{a}}$ & $0.33^{b}$ & $1146.00^{b}$ & $212.00^{b}$ & $24.75^{b}$ & $219.00^{b}$ \\
\hline & & \pm 0.08 & \pm 0.01 & \pm 53.45 & \pm 10.15 & \pm 0.79 & \pm 5.27 \\
\hline & F-prob & $0.000^{* * *}$ & $0.000^{* * *}$ & $0.000^{* * *}$ & $0.000^{* * *}$ & $0.000^{* * *}$ & $0.000^{* * *}$ \\
\hline \multirow{5}{*}{ Sandy } & \multirow{2}{*}{ Control } & $8.14^{b}$ & $0.05^{b}$ & $137.52^{a}$ & $23.08^{a}$ & $5.00^{\mathrm{a}}$ & $10.22^{a}$ \\
\hline & & \pm 0.13 & \pm 0.01 & \pm 4.46 & \pm 1.02 & \pm 0.09 & \pm 1.02 \\
\hline & \multirow{2}{*}{ Biostimulant } & $7.61^{\mathrm{a}}$ & $0.03^{\mathrm{a}}$ & $186.00^{\mathrm{c}}$ & $26.50^{b}$ & $6.90^{\mathrm{b}}$ & $12.33^{b}$ \\
\hline & & \pm 0.15 & \pm 0.01 & \pm 2.21 & \pm 0.44 & \pm 1.13 & \pm 0.48 \\
\hline & F-prob & $0.000^{* * *}$ & $0.000^{* * *}$ & $0.000^{* * *}$ & $0.000^{* * *}$ & $0.000 * * *$ & $0.006^{* *}$ \\
\hline
\end{tabular}

\subsection{Changes in Soil Organic Matter and Microbial Activity}

Biostimulants enhanced soil organic matter content and soil microbial activity in the two types of soils $(p<0.00)$ (Figure 1). The soil organic matter of the treated sandy soil was about 4 times greater $(0.40 \pm 0.04)$ than the control $(0.13 \pm 0.02)$, while the treated sandy loam soil showed an almost 2-fold $(0.68 \pm 0.01)$ increase in this parameter (Figure $1 \mathrm{~A}$ ) versus the control $(0.44 \pm 0.05)$. However, the soil microbial activity of the sandy soil treated with the biostimulant was about 3 times greater $(56.62 \pm 0.09)$ than the control (19.37 \pm 0.07$)$. In contrast, in the treated sandy loam soil (Figure 1B), the microbial activity was 2-fold greater $(193.66 \pm 12.00)$ than that of the control $(107.09 \pm 11.00)$.
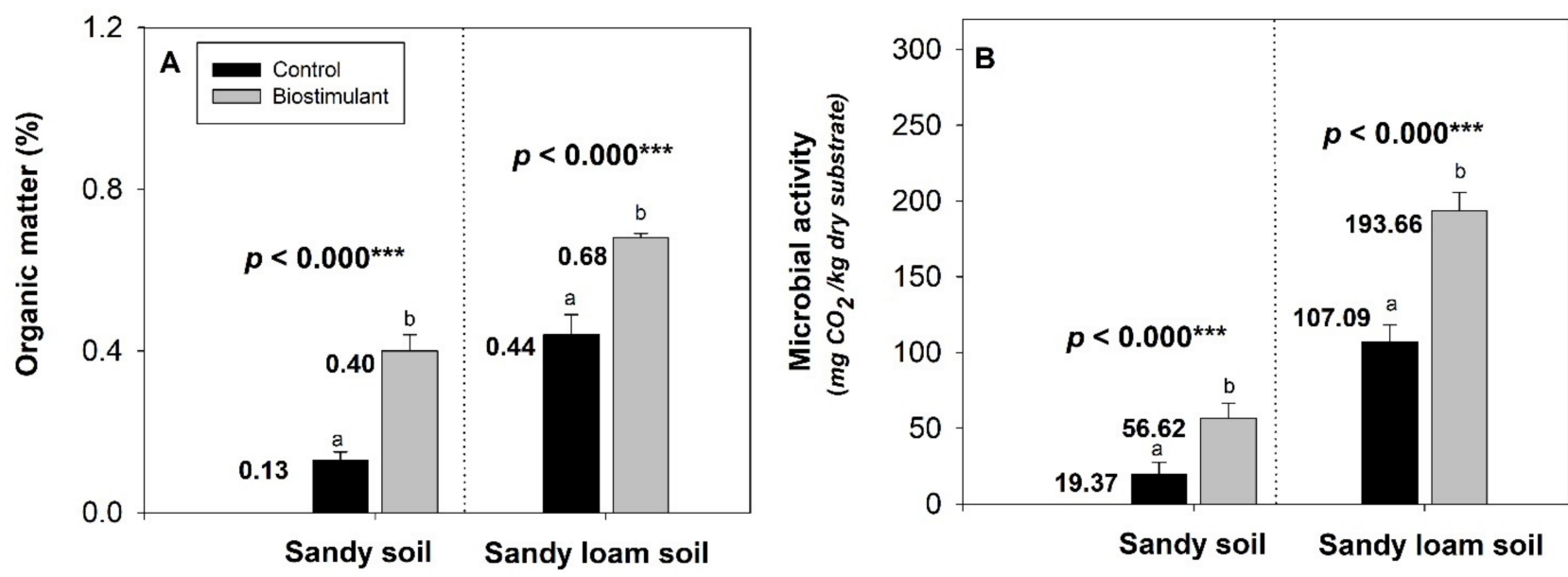

Figure 1. Mean values of soil organic matter (A) and microbial activity (B) of soil samples treated by biostimulant and control of about the two types of soil. Means followed by different letters are significantly different $(p<0.05)$ according to Tukey's HSD test. Significance levels: ${ }^{* * *} p<0.001$. 


\subsection{Effect of the Biostimulant on Soil Enzyme Activity}

The biostimulant had a significant effect on catalase, dehydrogenase, and phosphatase enzymatic activity (Figure 2A-C). Concerning catalase activity, the biostimulant increased the activity of this enzyme by about $15 \%$ in both sandy and sandy loam soils compared to the control. Similarly, dehydrogenase activity also increased in response to biostimulant and was greater $(4.30 \pm 0.12)$ than control $(3.18 \pm 0.05)$ by $35 \%$ in the sandy soil. However, in the sandy loam soil, dehydrogenase activity increased by about $8 \%$ (Figure 2B). Furthermore, the biostimulant had a significant effect on phosphatase activity in both soil types (Figure 2C), with an increase compared to control of about $90 \%$ and $77 \%$ in sandy soil and sandy loam soil, respectively (Figure 2C).

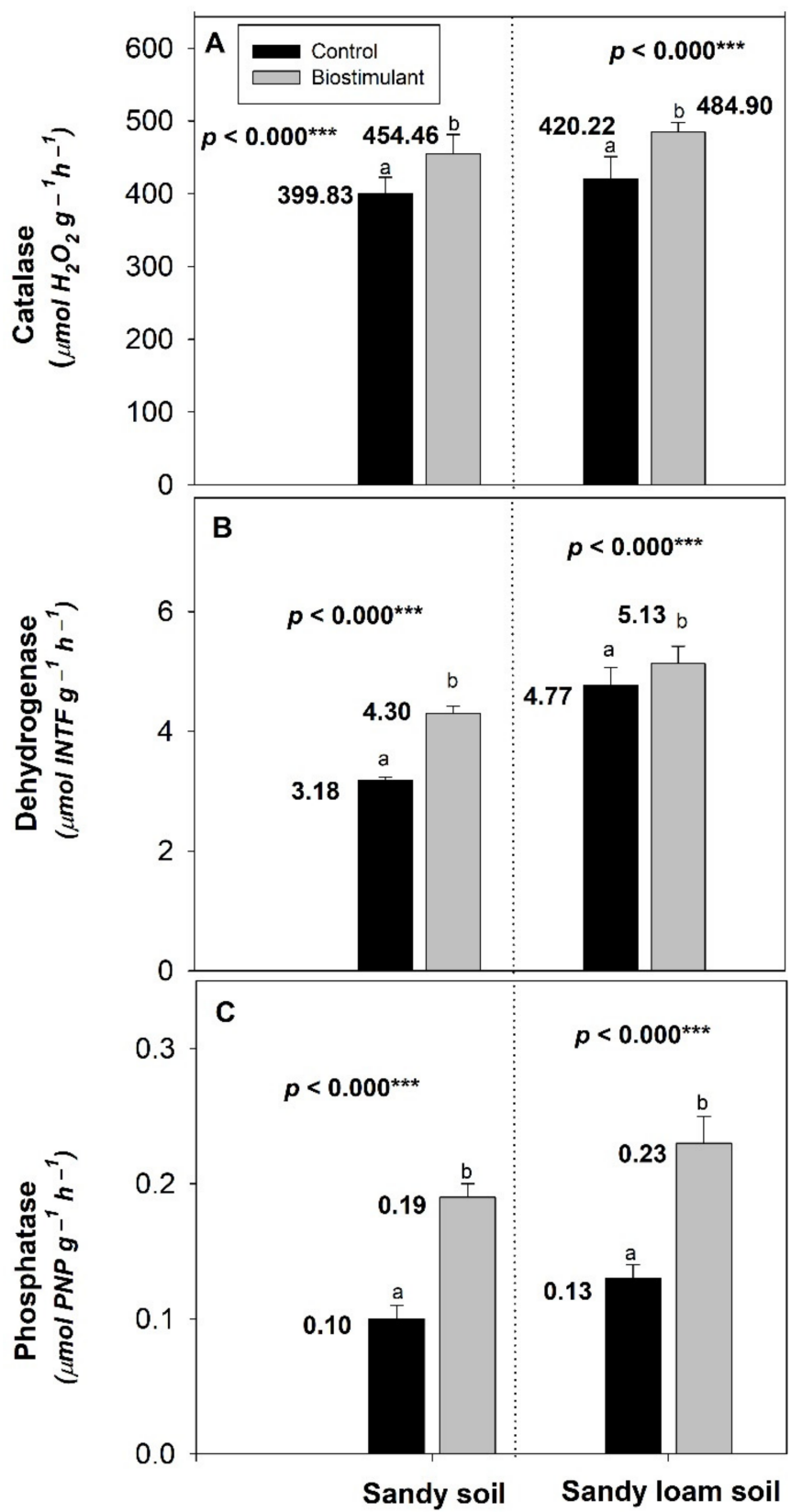

Figure 2. Mean values of catalase (A), dehydrogenase (B), and phosphatase (C) enzymatic activities of soil samples treated by biostimulant and control from the two type of soils. Means followed by different letters are significantly different $(p<0.05)$ according to Tukey's HSD test. Significance levels: $* * * p<0.001$. 


\subsection{Root Growth Evaluation}

Biostimulant application had a significant effect on the root growth (Figure 3) and in both soils. Root length in the two soil types increased strongly and significantly $(p<0.000)$ by about $34 \%$ and $43 \%$ in the sandy and sandy loam soils, respectively (Figure 3 ).

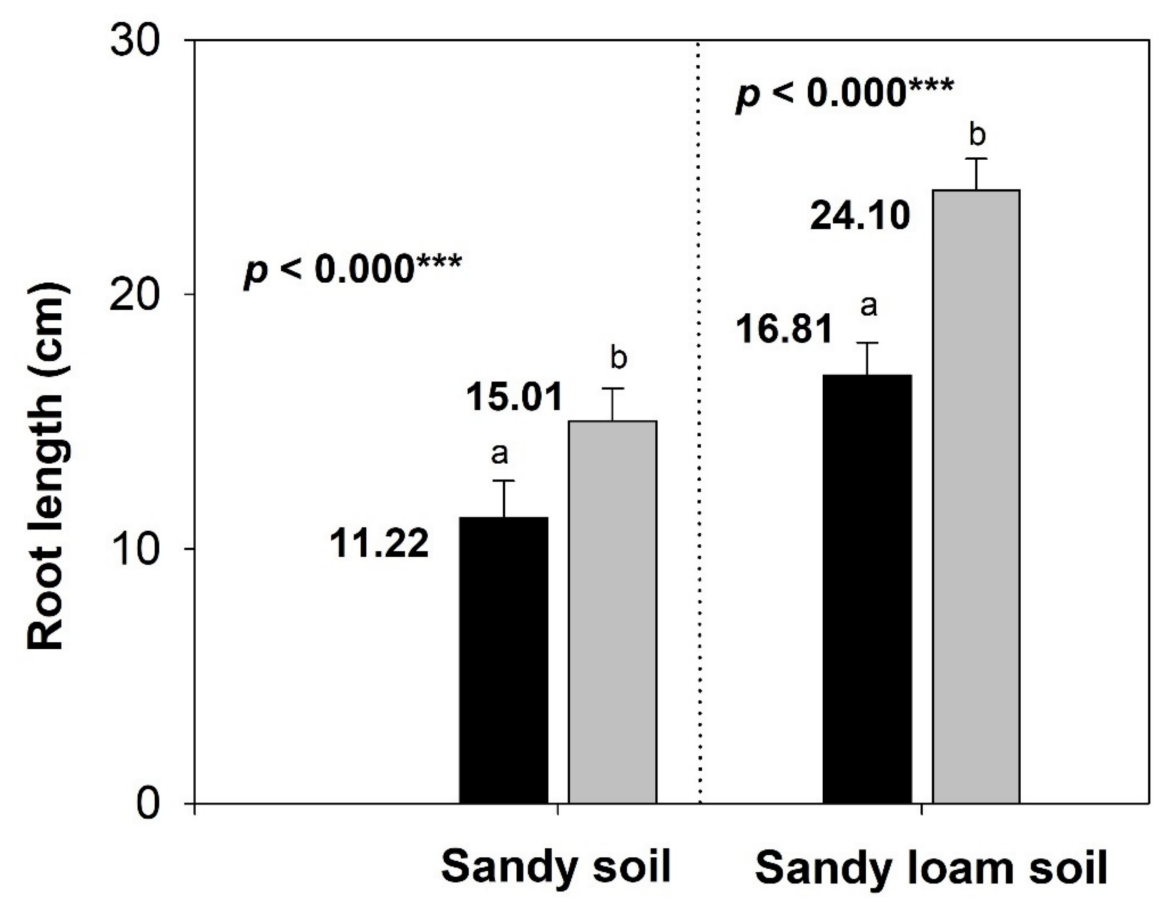

Figure 3. Mean values of root length of turfgrass plants under biostimulant, and control conditions from the two type of Scheme 0. Means followed by different letters are significantly different $(p<0.05)$ according to Tukey's HSD test. Significance levels: ${ }^{* * *} p<0.001$.

3.5. Relationships between the Growth Parameters and Soil Organic Matter, Microbial and Enzymatic Activities under Biostimulant Application

The activity of catalase, dehydrogenase, and phosphatase was positively related to root length across biostimulant application in both soils (Table 3). The highest coefficient correlation was found with dehydrogenase and catalase in both soils. Soil organic matter was also positively correlated with root length under both soils, with strong correlation under sandy soil $\left(0.704^{* *}\right)$ and a coefficient of $0.369 *$ in sandy loam soil. The microbial activity was correlated with roots length only under sandy soil (Table 3).

Table 3. Correlation coefficients of the linear relationships between organic matter, microbial activity, and enzymatic activities (catalase, dehydrogenase and phosphatase) with the root length under biostimulant condition from the two types of soils. Significance levels: ns, not significant; ${ }^{* *} p<0.01$; ${ }^{*} p<0.05$.

\begin{tabular}{ccc}
\hline & Sandy Loam Soil & Sandy Soil \\
\hline Catalase & $0.625^{* *}$ & $0.771^{* *}$ \\
Dehydrogenase & $0.606^{* *}$ & $0.460^{* *}$ \\
Phosphatase & $0.523^{* *}$ & $0.292^{*}$ \\
Microbial activity & $0.218^{\mathrm{ns}}$ & $0.340^{*}$ \\
Organic matter & $0.369^{*}$ & $0.704^{* *}$ \\
\hline
\end{tabular}

\subsection{Relationships between Root Growth and Chemical Soil Properties}

We also examined the relationships between the different ion signatures and root growth under biostimulant treatment in each soil type (Table 4). Under biostimulant application, root length correlated negatively with the $\mathrm{pH}$ and $\mathrm{EC}$ in sandy soil, while in 
the case of sandy loam soil, a negative correlation was found only with the $\mathrm{pH}$. Root length correlated positively only with $\mathrm{Ca}^{2+}$ and $\mathrm{P}$ in sandy loam soil, whereas in sandy soil strong correlations were found with $\mathrm{Ca}^{2+}, \mathrm{Mg}^{2+}$, and $\mathrm{K}^{+}$.

Table 4. The relationship of root length with soil $\mathrm{Ca}^{2+}, \mathrm{Mg}^{2+}, \mathrm{P}$, and $\mathrm{K}^{+}$content under biostimulant condition from the two types of soils. Levels of significance are as follows: $\mathrm{ns}$, not significant: ${ }^{* *} p<0.01$.

\begin{tabular}{ccc}
\hline & Sandy Loam Sandy Soil & Sandy Soil \\
\hline $\mathrm{Ca}^{2+}$ & $0.547^{* *}$ & $0.746^{* *}$ \\
$\mathrm{Mg}^{2+}$ & $0.115^{\mathrm{ns}}$ & $0.688^{* *}$ \\
$\mathrm{P}$ & $0.656^{* *}$ & $0.124^{\mathrm{ns}}$ \\
$\mathrm{K}+$ & $0.211^{\mathrm{ns}}$ & $0.456^{* *}$ \\
\hline
\end{tabular}

\subsection{Canonical Multivariable Analysis}

A canonical analysis (Figure 4) of all parameters studied was achieved with the two types of soils and the two tratements (Control and biostimulant). The two axes 1 and 2 explained together $99 \%$ of the total variance in the two types of soils and variables. The results showed that root length (RL) was associated with microbial activity, organic matter, and catalase activity (Figure 4). Moreover, $\mathrm{RL}$ was also related to $\mathrm{Ca}^{2+}, \mathrm{Mg}^{2+}, \mathrm{P}$, and $\mathrm{K}^{+}$, whereas $\mathrm{pH}$ and $\mathrm{EC}$ were not associated with roots growth.

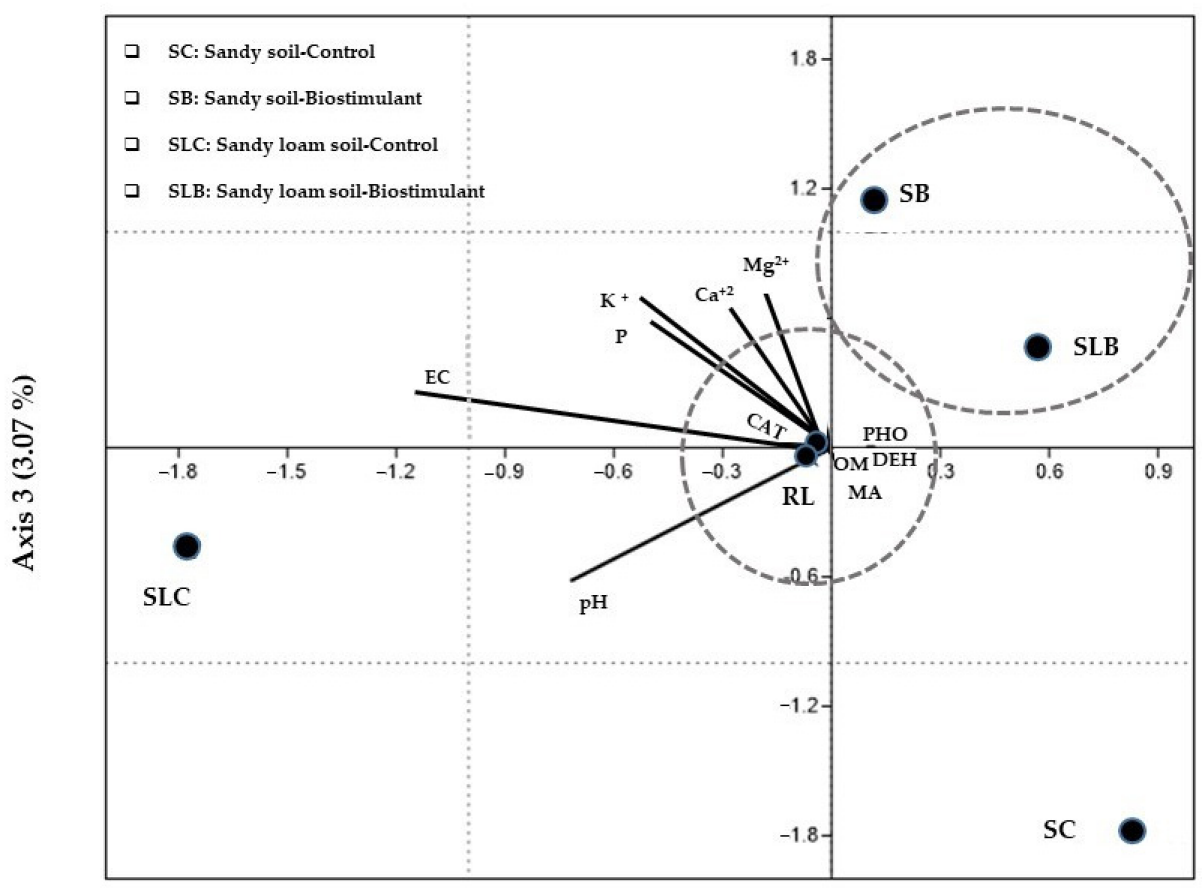

Axis $1(96.82 \%)$

Figure 4. Canonical analysis using, as a variable, all parameters measured for the two types of soil. CAT, Catalase; PHO, Phosphatase; DEH, Dehydrogenase; MA; Microbial activity; OM, Organic matter; RL, Root length.

In turn, the two types of soil with biostimulant application corresponded closely to enzyme activity and $\mathrm{Ca}^{2+}, \mathrm{Mg}^{2+}, \mathrm{P}$, and $\mathrm{K}^{+}$. However, the control of both soils (without application of biostimulant) was separated from the two soils with biostimulant and from enzymes activities and nutrient elements. 


\section{Discussion}

\subsection{Effect of Biostimulant on Soil Fertility and Microbial Activity}

This study demonstrated that biostimulant significantly increased soil organic matter content. Indeed, the organic biostimulant application has been reported to enhance the soil organic matter in most cases [52]. Similar to our results, authors [53] indicated that the organic particles that form fulvic acids promote soil organic matter. The improvement in soil organic matter content achieved by biostimulants can boost soil fertility and plays a significant role in soil sustainability by regulating the physical properties and nutrient balance of this matrix. Our study also revealed that treatment with biostimulant led to a significant increase in the microbial activity of the two soils studied, which is consistent with previous findings for amendments with fulvic acid [53]. Liquid or foliar forms of fulvic acid contain many small microbes that polarize soil [54] and enhance the microbial community of soils. The microbial activity improvement in our study is also due to the prebiotic molecules generated from the fermentation of humic acids and the probiotic molecules formed by a bacterial strain of Bacillus sublitis, which form the biostimulant. In this context, researchers [22] reported that prebiotics and probiotics are products which improve microbial diversity and soil microbial health by promoting the growth of soil microorganisms already present within the soil-plant system. The development of a healthy soil microbe community in response to biostimulant application has not only a direct effect on soil properties and fertility but also a higher indirect effect on plant growth. The soil microbial community is an essential factor influencing plant health since plant disease resistance depends on the rhizosphere microbial community [55]. Additionally, and given its rapid response and sensitivity to environmental changes, soil microbial activity has been considered an indicator of soil quality [56].

Moreover, our study also showed that the biostimulant decreased the soil $\mathrm{pH}$ and EC. These findings are consistent with those of another study examining fulvic acids as a soil amendment [52]. In this context, organic acids are responsible for decreasing soil pH, thereby releasing phosphate ions [57]. Moreover, due to the calcium lignosulfonate content of the biostimulant used, the permeability of the substrates increased, implying a decrease in conductivity and $\mathrm{pH}$. According to our results, the decrease in soil $\mathrm{pH}$ permitted the assimilation and availability of $\mathrm{Ca}^{2+}, \mathrm{Mg}^{2+}, \mathrm{K}^{+}$, and P plant nutrient elements. Biostimulants affected the chemical composition of the soil, improving the content of $\mathrm{Ca}^{2+}, \mathrm{Mg}^{2+}$, $\mathrm{K}^{+}$, and P. According to this, researchers [58] stated that biostimulants containing fulvic acids increase the $\mathrm{N}, \mathrm{P}$ and $\mathrm{K}^{+}$content of soil. Therefore, we conclude that biostimulant application contributes to soil enrichment in plant nutrient elements and facilities plant accessibility, allowing better growing conditions and preserving and improving soil structure and chemical composition.

\subsection{Biostimulants and Soil Enzyme Activity}

Given that many of the reactions and metabolisms occurring in the soil are related to enzymatic activity, we examined the biostimulant effect on catalase, dehydrogenase, and phosphatase activity. Biostimulant application increased the catalase, dehydrogenase, and phosphatase activities. These results are consistent with the findings of other studies $[30,59,60]$. In this regard, the treatment of soil with organic fertilizers stimulates microbial growth and increases enzymatic activity compared to the use of inorganic fertilizers alone [30]. Other studies recognize that the increase in enzymatic activity that occurs after a soil amendment with biostimulants is due to the input of organic substrates, which stimulate microbial growth and enzyme synthesis [61,62]. The authors of a previous study [59] also added that the increase in enzymatic activity could be explained by the degradation of the organic acids of the biostimulant by soil microorganisms - soil being the richest carbon source, thus leading to greater induction of microbial metabolism. Moreover, since most biostimulants have a high percentage of proteins, they markedly increase soil enzymatic activity, induce changes in the microbial community, and have a considerable effect on soil biological properties, possibly because the low molecular weight protein content can 
be easily assimilated by soil microorganisms [30]. The increase of dehydrogenase and catalase activities evaluated in both soils with biostimulant in our study was comparable to that observed in soil microbial activity and organic matter. In this regard, dehydrogenase activity changes reflect soil status [60] and have been proposed as a good indicator of soil microbial activity [59]. Dehydrogenase and catalase activities are representative of different chemical and biological cycles of importance in soils such as carbon, nitrogen and phosphorus [63]. Furthermore, catalase has been used as an index of soil fertility [64], as well as dehydrogenase activity [63]. Moreover, our results indicate biostimulant incited higher phosphatase activity in both soils (sandy loam and sandy soil). This enzyme activity increased phosphorus bioavailability in soils [61]; excretion of hydrolytic enzymes is stimulated by signals from these enzymes under nutrient-limited growth conditions [65]. The increase in the activity of all the enzymes evaluated in this study in response to biostimulants confirms the positive effect of this treatment on soil enzyme metabolism and mechanisms, which in turn enhance soil properties and plant growth.

\subsection{Improving Root Growth with Biostimulant Application}

Regarding plant growth, we observed a positive effect of the biostimulant application on root length. In this context, several studies have reported that treatment of plants with humic substances of distinct origin induces the proliferation of lateral roots and root hairs $[66,67]$. The improvement in root growth obtained by biostimulant application can help plants access soil nutrients and water at different depths. Biostimulant substances lead to nutrient accumulation in soil, thereby increasing their availability and favoring greater root growth $[18,68,69]$.

Additionally, we consider that the higher root performance under biostimulant application is due to the rhizogenic effect of fulvic acids of the biostimulant. Moreover, authors [70] reported that organic biostimulant already contains many proteins decomposed during the fermentation process and humidified into amino acids. The authors reported that amino acids activate bacterial life in the soil and stimulate root activity in crops [70]. Our results also revealed a significant correlation between root length and the soil enzyme activities, organic matter, microbial activity and nutrient under the biostimulant application in the two types of soil. The canonical analysis supports these associations and confirms that soil with biostimulant is related to enzymatic activities, organic matter, and nutrient content, enhancing root growth.

\subsection{Biostimulant and Soil Texture}

This study analyzed the effect of biostimulant on two types of soil, sandy loam, and sandy soil. The biostimulant improve soil biological activity and chemical composition in both soil, but to a different degree. The percentage of improvement was higher in sandy soil compared to sandy loam soil. These findings confirm the need to test the soil before applying any biostimulant. Knowledge of texture, availability, and nutrient content in the soil will enable more appropriate decisions regarding the most suitable biostimulant application in each soil. The amount of biostimulant and the number of applications depend on soils type (very poor like sandy soil, or soil with moderate fertility) and crop requirements. Thus, the difference in the degree of the response to the biostimulant observed by the two types of soil highlights the relevance of analyzing soil before biostimulant application and understanding all components of each amendment.

\section{Conclusions}

This study showed that the application of the biostimulant improved the physical and chemical composition of sandy loam and sandy soils as well as its biological community, enzymatic activity and root accessibility to soil nutrients. Similarly, regarding plant morphology, root growth increased with biostimulant application. Our results also showed differences in the response of the two types of soils to the biostimulant application. We recommend soil analysis (texture and chemical composition) to allow an informed decision 
regarding the quantity and number of applications suitable for each type of soil. Finally, this study reveals the capacity of biostimulant to correct and improve soil deficits and fertility. Biostimulants offer an opportunity to circumvent the excessive use of chemical fertilizers, which lead to a deterioration of the structure and biological composition of soils and thus to contribute to environmental protection. In summary, we conclude that biostimulant treatments can help to preserve soil health and ecosystems, and enhance root plant growth, which contribute to improved plant development and productivity. The smart strategies of soil amendments with biostimulants can support sustainable agriculture and contribute to environmental protection. In future work, we would like to study the effect of biostimulants on the crop over several years, focusing on the expected enhanced health. To evaluate the changes in the plant vigor, plant quality, and vegetation status, we will use spectral reflectance approach like the Greenseeker device to measure the normalized difference vegetation index (NDVI) and drone imagery (true color and thermal imagery). Root architecture and biomass will be evaluated with the aim of assessing the effect of biostimulants in the plant radicular system. Furthermore, and linked to the turfgrass quality, we will evaluate the effect of biostimulants in the prevalence of plant diseases and weed plants according to the methodology described previously [71]. Additionally, all parameters evaluated in this study (enzyme activity, soil nutrient and microbial activity) will be evaluated in future work, with the aim of determining the persistence of the observed changes in soil properties. Finally, we will evaluate if the enhanced plant vigor and improved soil characteristics can help turfgrass to tolerate severe hydric stress compared to that generated in a previous study [72]. On the other hand, we will also compare the changes in soil properties and roots using biostimulants with different composition.

Author Contributions: Conceptualization, J.M., S.Y. and P.V.M.; Methodology, J.M.; S.Y., and P.V.M.; Field measures and sampling, S.Y.; Formal analysis, S.Y.; Data curation, S.Y.; Writing-original draft preparation, S.Y.; Writing—review and editing, S.Y., P.V.M., J.L., L.P., and J.M.; Supervision, J.M., J.L., and P.V.M.; Validation, J.M., J.L., and P.V.M.; Project administration, J.M. and P.V.M. All authors have read and agreed to the published version of the manuscript.

Funding: This research was funded by AREA VERDE-MG projects, by project PDR18-XEROCESPED, funded under the PDR-CM 2014-2020 by the EU (European Agricultural Fund for Rural Development, EAFRD), Spanish Ministry of Agriculture, Fisheries and Food (MAPA) and Comunidad de Madrid regional government through IMIDRA. and by a post-doc grant by Conselleria de Educación, Cultura y Deporte through "Subvenciones para la contratación de personal investigador en fase postdoctoral", reference APOSTD/2019/04.

Data Availability Statement: The data presented in this study are available on request from the corresponding author. The data are not publicly available due to privacy constrains.

Acknowledgments: We acknowledge David Pérez Ansotegui, crop technology manager in Agrotechnology Group (Alicante, Spain) and Pilar García-Gonzalo from Departamento de Investigación Agroambiental (IMIDRA) for their collaboration.

Conflicts of Interest: The authors declare no conflict of interest. The funders had no role in the design of the study; in the collection, analyses, or interpretation of data; in the writing of the manuscript, or in the decision to publish the results.

\section{References}

1. Khan, M.; Mobin, M.; Abbas, Z.; Alamri, S. Fertilizers and Their Contaminants in Soils, Surface and Groundwater. In Encyclopedia of the Anthropocene; DellaSala, D.A., Goldstein, M.I., Eds.; Elsevier: Oxford, UK, 2018; Volume 5, pp. $225-240$.

2. Körschens, M.; Albert, E.; Armbruster, M.; Barkusky, D.; Baumecker, M.; Behle-Schalk, L.; Bischoff, R.; Čergan, Z.; Ellmer, F.; Herbst, F.; et al. Effect of mineral and organic fertilization on crop yield, nitrogen uptake, carbon and nitrogen balances, as well as soil organic carbon content and dynamics: Results from 20 European long-term field experiments of the twenty-first century. Arch. Agron. Soil Sci. 2013, 59, 1017-1040. [CrossRef]

3. Leroy, B.L.M.; Herath, H.M.S.K.; Sleutel, S.; De Neve, S.; Gabriëls, D.; Reheul, D.; Moens, M. The quality of exogenous organic matter: Short-term effects on soil physical properties and soil organic matter fractions. Soil Use Manag. 2008, $24,139-147$. [CrossRef] 
4. Wang, J.; Li, R.; Zhang, H.; Wei, G.; Li, Z. Beneficial bacteria activate nutrients and promote wheat growth under conditions of reduced fertilizer application. BMC Microbiol. 2020, 20,38. [CrossRef]

5. Zhang, Q. Optimal schemes and correlation analysis between soil nutrient, $\mathrm{pH}$ and microorganism population in orchard of Beijing suburb. Fruit Sci. 2020, 28, 15-19.

6. Bell, C.W.; Asao, S.; Calderon, F.; Wolk, B.; Wallenstein, M.D. Plant nitrogen uptake drives rhizosphere bacterial community assembly during plant growth. Soil Biol. Biochem. 2015, 85, 170-182. [CrossRef]

7. Singh, J.S.; Gupta, V.K. Soil microbial biomass: A key soil driver in management of ecosystem functioning. Sci. Total Environ. 2018, 634, 497-500. [CrossRef]

8. Wu, L.; Jiang, Y.; Zhao, F.; He, X.; Liu, H.; Yu, K. Increased organic fertilizer application and reduced chemical fertilizer application affect the soil properties and bacterial communities of grape rhizosphere soil. Sci. Rep. 2020, 10, 9568. [CrossRef]

9. John, K.; Isong, I.A.; Kebonye, N.M.; Ayito, E.O.; Agyeman, P.C.; Afu, S.M. Using Machine Learning Algorithms to Estimate Soil Organic Carbon Variability with Environmental Variables and Soil Nutrient Indicators in an Alluvial Soil. Land 2020, 9, 487. [CrossRef]

10. Randeep, K.; Ravendra, K.; Om, P. The Impact of Chemical Fertilizers in Our Environment and Ecosystem. Available online: https: / / www.researchgate.net/publication/331132826 (accessed on 17 March 2021).

11. Zhang, X.; Schmidt, R. Biostimulating turfgrasses. Grounds Maint. 1999, 34, 14-15.

12. Schmidt, R.E.; Ervin, E.H.; Zhang, X. Questions and answers about biostimulants. Golf Course Manag. 2003, 71, 91-94.

13. Du Jardin, P. The Science of Plant Biostimulants. A Bibliographic Analysis, Adhoc Study Report; European Commission: Brussels, Belgium, 2012; Available online: http:/ / hdl.handle.net/2268/169257 (accessed on 17 March 2021).

14. Kawalekar, J.S. Role of biofertilisers and biopesticides for sustainable agriculture. J. Biol. Innov. 2013, 2, 73-78.

15. Abdel-Raouf, N.; Al-Homaidan, A.A.; Ibraheem, I.B.M. Microalgae and wastewater treatment. Saudi J. Biol. Sci. 2012, 19, 257-275. [CrossRef] [PubMed]

16. Halpern, M.; Bar-Tal, A.; Ofek, M.; Minz, D.; Muller, T.; Yermiyahu, U. The Use of Biostimulants for Enhancing Nutrient Uptake. Adv. Agron. 2015, 130, 141-174. [CrossRef]

17. Drobek, M.; Frąc, M.; Cybulska, J. Plant Biostimulants: Importance of the Quality and Yield of Horticultural Crops and the Improvement of Plant Tolerance to Abiotic Stress-A Review. Agronomy 2019, 9, 335. [CrossRef]

18. Du Jardin, P. Plant biostimulants: Definition, concept, main categories and regulation. Sci. Hortic. 2015, 196, 3-14. [CrossRef]

19. Chiaiese, P.; Corrado, G.; Colla, G.; Kyriacou, M.C.; Rouphae, Y. Renewable sources of plant biostimulation as a sustainable means to improve crop performance. Front. Plant Sci. 2018, 9, 1-6. [CrossRef]

20. Strachel, R.; Wyszkowska, J.; Baćmaga, M. The Role of Compost in Stabilizing the Microbiological and Biochemical Properties of Zinc-Stressed Soil. Water Air Soil Pollut. 2017, 228, 349. [CrossRef]

21. Javaid, A. Foliar application of effective microorganisms on pea as an alternative fertilizer. Agron. Sustain. Dev. 2006, 26, 257-262. [CrossRef]

22. Vassileva, M.; Flor-Peregrin, E.; Malusá, E.; Vassilev, N. Towards Better Understanding of the Interactions and Efficient Application of Plant Beneficial Prebiotics, Probiotics, Postbiotics and Synbiotics. Front. Plant Sci. 2020, 11, 1068. [CrossRef]

23. Quilty, J.R.; Cattle, S.R. Use and understanding of organic amendments in Australian agriculture: A review. Soil Res. 2011, 49, 1-26. [CrossRef]

24. Seyedbagheri, M.-M. Influence of Humic Products on Soil Health and Potato Production. Potato Res. 2010, 53, 341-349. [CrossRef]

25. Brady, N.C.; Weil, R.R. The Nature and Properties of Soils; Pearson Prentice Hall: Upper Saddle River, NJ, USA, 2008.

26. Calvo, P.; Nelson, L.; Kloepper, J.W. Agricultural uses of plant biostimulants. Plant Soil 2014, 383, 3-41. [CrossRef]

27. Saviozzi, A.; Levi-Minzi, R.; Cardelli, R.; Riffaldi, R. A comparison of soil quality in adjacent cultivated, forest and native grassland soils. Plant Soil 2001, 233, 251-259. [CrossRef]

28. Gezerman, A.O.; Çorbacioglu, B.D. Effects of Calcium Lignosulfonate and Silicic Acid on Ammonium Nitrate Degradation. J. Chem. 2014, 2014, 426014. [CrossRef]

29. Karol, R.H. Chemical Grouting and Soil Stabilization, 3rd ed.; Marcel Dekker: New York, NY, USA, 2003 ; pp. 25-37.

30. Tejada, M.; Benítez, C.; Gómez, I.; Parrado, J. Use of biostimulants on soil restoration: Effects on soil biochemical properties and microbial community. Appl. Soil Ecol. 2011, 49, 11-17. [CrossRef]

31. Nardi, S.; Carletti, P.; Pizzeghello, D.; Muscolo, A. Biological activities of humic substances, in biophysicochemical processes involving natural nonliving organic matter in environmental systems. In Part I. Fundamentals and Impact of Mineral-Organic-Biota Interactions on the Formation, Transformation, Turnover, and Storage of Natural Nonliving Organic Matter (NOM); Senesi, N., Xing, B., Huang, P.M., Eds.; John Wiley: Hoboken, NJ, USA, 2009.

32. Giannattasio, M.; Vendramin, E.; Fornasier, F.; Alberghini, S.; Zanardo, M.; Stellin, F.; Concheri, G.; Stevanato, P.; Ertani, A.; Nardi, S.; et al. Microbiological features and bioactivity of a fermented manure product (Preparation 500) used in biodynamic agriculture. J. Microbiol. Biotechnol. 2013, 23, 644-651. [CrossRef]

33. Chen, S.-K.; Subler, S.; Edwards, C.A. Effects of agricultural biostimulants on soil microbial activity and nitrogen dynamics. Appl. Soil Ecol. 2002, 19, 249-259. [CrossRef]

34. European Biostimulants Industry Council, EBIC. 2012. Available online: http://www.biostimulants.eu/ (accessed on 27 September 2014). 
35. Dick, R.P.; Rasmussen, P.E.; Kerle, E.A. Influence of long-term residue management on soil enzyme activities in relation to soil chemical properties of a wheat-fallow system. Biol. Fertil. Soils 1988, 6, 159-164. [CrossRef]

36. Frankenberger, W.T.; Dick, W.A. Relationships between enzyme activities and microbial growth and activity indices in soil. Soil Sci. Soc. Am. J. 1983, 47, 945-951. [CrossRef]

37. Karaca, A.; Cetin, S.C.; Turgay, O.C.; Kizilkaya, R. Soil enzymes as indication of soil quality. In Soil Enzymology; Springer: Berlin/Heidelberg, Germany, 2010; Available online: https://www.researchgate.net/publication/226037282 (accessed on 17 March 2021).

38. Masciandaro, G.; Ceccanti, B.; Ronchi, V.; Benedicto, S.; Howard, L. Humic substances to reduce salt effect on plant germination and growth. Commun. Soil Sci. Plant Anal. 2002, 33, 365-378. [CrossRef]

39. Burns, R.G. Enzyme activity in soil. Soil Biol. Biochem. 1982, 14, 423-427. [CrossRef]

40. Lemanowicz, J. Dynamics of phosphorus content and the activity of phosphatase in forest soil in the sustained nitrogen compounds emissions zone. Environ. Sci. Pollut. Res. 2018, 25, 33773-33782. [CrossRef]

41. Colla, G.; Rouphael, Y.; DiMattia, E.; El-Nakhel, C.; Cardarelli, M. Coinoculation of Glomus intraradices and Trichoderma atroviride acts as a biostimulant to promote growth, yield and nutrient uptake of vegetable crops. J. Sci. Food Agric. 2015, 95, 1706-1715. [CrossRef] [PubMed]

42. Ertani, A.; Pizzeghello, D.; Baglieri, A.; Cadili, V.; Tambone, F.; Gennari, M.; Nardi, S. Agro-industrial residues and their biological activity on maize (Zea mays L.) metabolism. J. Geochem. Explor. 2012, 129, 103-111. [CrossRef]

43. Malik, K.A.; Azam, F. Effect of humic acid on wheat (Triticum aestivum L.) seedling growth. Environ. Exp. Bot. 1985, 25, 245-252. [CrossRef]

44. Zandonadi, D.B.; Santos, M.P.; Dobbss, L.B.; Olivares, F.L.; Canellas, L.P.; Binzel, M.L.; Okorokova-Façanha, A.L.; Façanha, A.R. Nitric oxide mediates humic acids-induced root development and plasma membrane H+-ATPase activation. Planta 2010, 231, 1025-1036. [CrossRef]

45. Olsen, S.; Cole, C.; Watanabe, F.; Dean, L. Estimation of Available Phosphorus in Soils by Extraction with Sodium Bicarbonate; USDA Circular No. 939; U.S. Government Printing Office: Washington, DC, USA, 1954.

46. Gracía, C.; Hernandez, T. Microbial activity in degraded soils under semiarid climate. Change with their rehabilitation. In Preserving Soil Quality and Soil Biodiversity. The Role of Surrogate Indicators; Lobo, M.C., Ibañez, J.J., Eds.; Sdad Coop. De Artes Gráficas: Zaragoza, Spain, 2003; ISBN 84-451-2434-X.

47. Walkley, A.; Black, I.A. An examination of the degtjareff method for determining soil organic matter, and a proposed modification of the chromic acid titration method. Soil Sci. 1934, 37, 29-38. [CrossRef]

48. Trevors, J.T.; Mayfield, C.I.; Inniss, W.E. Measurement of Electron Transport System (ETS) activity in soil. Microb. Ecol. 1982, 8, 163-168. [CrossRef] [PubMed]

49. García, C.; Hernández, T.; Costa, F.; Ceccanti, B.; Masciandaro, G. The dehydrogenase activity of soil as an ecological marker in processes of perturbed system regeneration. In Proceedings of the XI International Symposium of Environmental Biochemistry, Salamanca, Spain, 27 September-1 October 1993; Gallardo-Lancho, J., Ed.; CSIC: Salamanca, Spain, 1993; pp. 89-100.

50. Johnson, J.L.; Temple, K.L. Some variables affecting the measurement of "Catalase activity" in soil. Soil Sci. Soc. Am. Proc. 1964, 28, 207-209. [CrossRef]

51. Tabatabai, M.A.; Bremner, J.M. Use of p-nitrophenyl phosphate for assay of soil phosphatase activity. Soil Biol. Biochem. 1969, 4, 301-307. [CrossRef]

52. Wang, L.; Sun, X.; Li, S.; Zhang, T.; Zhang, W.; Zhai, P. Application of Organic Amendments to a Coastal Saline Soil in North China: Effects on Soil Physical and Chemical Properties and Tree Growth. PLoS ONE 2014, 9, e89185. [CrossRef]

53. Sootahar, M.K.; Zeng, X.; Su, S.; Wang, Y.; Bai, L.; Zhang, Y.; Li, T.; Zhang, X. The Effect of Fulvic Acids Derived from Different Materials on Changing Properties of Albic Black Soil in the Northeast Plain of China. Molecules 2019, 24, 1535. [CrossRef]

54. Robert, E.P. Organic matter, humus, humate, humic acid, fulvic acid and humin: Their importance in soil fertility and plant health. In Proceedings of the IEEE Geoscience and Remote Sensing Symposium (IGARSS) 2014, Quebec City, QC, Cananda, 13-18 July 2014; pp. 1-5.

55. Yuan, J.; Zhao, M.; Li, R.; Huang, Q.; Rensing, C.; Shen, Q. Lipopeptides produced by B. amyloliquefaciens NJN-6 altered the soil fungal community and non-ribosomal peptides genes harboring microbial community. Appl. Soil Ecol. 2017, 117-118, 96-105. [CrossRef]

56. Xu, L.; Yi, M.; Yi, H.; Guo, E.; Zhang, A. Manure and mineral fertilization change enzyme activity and bacterial community in millet rhizosphere soils. World J. Microbiol. Biotechnol. 2017, 34, 8. [CrossRef] [PubMed]

57. Rodríguez, H.; Fraga, R.; Gonzalez, T.; Bashan, Y. Genetics of phosphate solubilization and its potential applications for improving plant growth-promoting bacteria. Plant Soil 2006, 287, 15-21. [CrossRef]

58. Tahir, M.; Khurshid, M.; Khan, M.; Abbasi, M.; Kazmi, M.; Tahir, M.; Khurshid, M.; Khan, M.; Abbasi, M.; Kazmi, M. LigniteDerived Humic Acid Effect on Growth of Wheat Plants in Different Soils. Pedosphere 2011, 21, 124-131. [CrossRef]

59. Macias-Benitez, S.; Garcia-Martinez, A.M.; Jimenez, P.C.; Gonzalez, J.M.; Moral, M.T.; Rubio, J.P. Rhizospheric Organic Acids as Biostimulants: Monitoring Feedbacks on Soil Microorganisms and Biochemical Properties. Front. Plant Sci. 2020, 11, 633. [CrossRef] 
60. Niewiadomska, A.; Sulewska, H.; Wolna-maruwka, A.; Ratajczak, K.; Waraczewska, Z.; Budka, A.; Głuchowska, K. The influence of biostimulants and foliar fertilisers on the process of biological nitrogen fixation and the level of soil biochemical activity in soybean (Glycine max L.) cultivation. Appl. Ecol. Environ. Res. 2019, 17, 12649-12666. [CrossRef]

61. Lazcano, C.; Gómez-Brandón, M.; Revilla, P.; Domínguez, J. Short-term effects of organic and inorganic fertilizers on soil microbial community structure and function. Biol. Fertil. Soils 2013, 49, 723-733. [CrossRef]

62. Pascual, J.A.; García, C.; Hernandez, T. Lasting microbiological and biochemical effects of the addition of municipal solid waste to an arid soil. Biol. Fertil. Soils 1999, 30,1-6. [CrossRef]

63. Marcote, I.; Hernández, T.; García, C.; Polo, A. Influence of one or two successive annual applications of organic fertilizers on the enzyme activities of a soil under barley cultivation. Bioresour. Technol. 2001, 79, 147-154. [CrossRef]

64. Alvear, M.; Pino, M.; Castillo, C.; Trasar-Cepeda, C.; Gil-Sotres, F. Efecto de las cero labranza sobre algunas actividades biológicas en un alfisol del sur de chile. J. Soil Sci. Plant Nutr. 2006, 2, 38-53. [CrossRef]

65. García-Álvarez, A.; Ibañez, J.J. Seasonal fluctuations and crop influence on microbiota and enzyme activity in fully developed soils of central Spain. Arid. Soil Res. Rehabil. 1994, 8, 161-178. [CrossRef]

66. Cezairliyan, B.; Ausubel, F.M. Investment in secreted enzymes during nutrient-limited growth is utility dependent. Proc. Natl. Acad. Sci. USA 2017, 114, E7796-E7802. [CrossRef]

67. Canellas, L.P.; Olivares, F.L.; Okorokova-Façanha, A.L.; Façanha, A.R. Humic Acids Isolated from Earthworm Compost Enhance Root Elongation, Lateral Root Emergence, and Plasma Membrane H+-ATPase Activity in Maize Roots. Plant Physiol. 2002, 130, 1951-1957. [CrossRef]

68. Nardi, S.; Pizzeghello, D.; Muscolo, A.; Vianello, A. Physiological effects of humic substances on higher plants. Soil Biol. Biochem. 2002, 34, 1527-1536. [CrossRef]

69. Barone, V.; Baglieri, A.; Stevanato, P.; Broccanello, C.; Bertoldo, G.; Bertaggia, M.; Cagnin, M.; Pizzeghello, D.; Moliterni, V.M.C.; Mandolino, G.; et al. Root morphological and molecular responses induced by microalgae extracts in sugar beet (Beta vulgaris L.). J. Appl. Phycol. 2018, 30, 1061-1071. [CrossRef]

70. Ferm o Feed. Fertilizantes Orgánicos. Available online: https://es.fermofeed.com/acerca-de-los-fertilizantes/\%C3\%A1cidos-h\% C3\%BAmicos-y-amino\%C3\%A1cidos (accessed on 17 March 2021).

71. Parra, L.; Marin, J.; Yousfi, S.; Rincón, G.; Mauri, P.V.; Lloret, J. Edge detection for weed recognition in lawns. Comput. Electron. Agric. 2020, 176, 105684. [CrossRef]

72. Marín, J.; Yousfi, S.; Mauri, P.V.; Parra, L.; Lloret, J.; Masaguer, A. RGB Vegetation Indices, NDVI, and Biomass as Indicators to Evaluate C3 and C4 Turfgrass under Different Water Conditions. Sustainability 2020, 12, 2160. [CrossRef] 